\title{
Organizational Culture and Impact on Opportunities for Professional Advancement
}

\author{
Phoebe Massimino* \\ Business and Economics \\ York College, City University of New York \\ Kay Turner \\ Human Resources \\ Fordham University
}

\begin{abstract}
This paper explores why some demographics, who are relatively new to the ranks of white collar corporate America, may encounter difficulties while navigating the unwritten rules that create the foundation for success in contemporary corporate culture; and suffer unintended consequences to their employment and career advancement. Here we discuss evolving paradigms of diversity initiatives including diversity as demographics vs. diversity of ideas, and how organizational culture may impact the attainment of diversity goals, and by extension, attainment of promotional opportunities for corporate novices. Finally, this paper will examine the role of business organizations in valuing diversity, and the obligation of educational institutions in preparing diverse candidates with knowledge of business etiquette and valuing business culture.
\end{abstract}

Keywords: Organizational Culture, Career Advancement, Business Etiquette, Diversity, Management Education

* Corresponding Author. pmassimino@york.cuny.edu 


\section{The Role of Culture}

Throughout the millennia, culture has shaped the human species and helped it to survive. Culture governs how people relate to each other and the world around them. From the type of shelter we choose, to the clothing we wear and even the food we eat, or refuse to eat, culture informs our daily interactions. Defined as norms, values, and practices, culture heavily influences how people relate to one another. It establishes prescriptive norms for acceptable behaviors with the ultimate goal of preserving the group. These normative conventions have been ported to all types of social constructs including governments and industry. Over time, business organizations have developed their own norms, values, and practices, where group members who adhere to these widely accepted customs receive the support of the group. Members who are culturally "in the know" gain considerable advantage over those who are not.

"Culture" has been a well-documented source of discussion and debate for several decades. As early as 1937, Margaret Mead, a noted cultural anthropologist, proposed that culture, "can mean the forms of traditional behavior which are characteristic of a certain society, or of a group of societies, or of a certain race, or of a certain area, or of a certain period of time" (1937, pp. 17-18). The concept was further described,

As the totality of the mental and physical reactions and activities that characterize the behavior of the individuals composing a social group collectively and individually in relation to their natural environment, to other groups, to members of the group itself and of each individual to himself. (Boas, 1938, p. 159)

By 1985, culture was viewed as, “...the system of standards or rules for perceiving, believing, and acting that one needs to know in order to operate in a manner acceptable to the members of the culture" (Ouchi \& Wilkins, 1985, p. 461). With noted author Edgar Schein (1996) adding that, “... culture, viewed as such taken-for-granted, shared, tacit ways of perceiving, thinking and reacting, was one of the most powerful and stable forces operating in organizations" (p. 231).

\section{Culture is Manifested through Values, Norms, and Practices}

Culture is manifested through values, norms, and practices - sometimes referred to as behaviors. Though each may vary from society to society, values generally "are broad-based beliefs that signal what is desirable and undesirable in an environment" (Daniels \& Greguras, 2014, p. 1203). Within a work context, Sutarjo (2011) states that cognitive work values relate to beliefs about appropriate behaviors and having meaningful work.

Norms have been traditionally defined as the customary rules that govern behavior in groups and societies (Schein, 1996; McDonald \& Westphal, 2013; Rakoczy \& Schmidt, 2013). Norms play a significant role in influencing member behaviors or practices, because group members who adhere to norms receive support and rewards from other group members (McDonald \& Westphal, 2013). Notably, “... behind the norms lies this deeper taken-for-granted set of assumptions that most members of a culture never question or examine. The members of a culture are not even aware of their own culture until they encounter a different one" (Schein, 1996, p. 236).

Other authors have expanded their scope of examination to include culture's role in defining, governing and influencing specific kinds of behaviors and practices in various settings. For example: Stohl 
(1986) states that "culture related knowledge refers to the acquisition of information regarding how things get done, what meanings are ascribed to behavior, organizational values, and so on" (p. 237). Finally, we are told that culture essentially includes expectations humans have of each other in the context of living and working together (Goodenough, 2003).

\section{Organizations and Businesses Have their Own Culture and Socialization Practices}

Organizational culture sets expectations for behavior. The majority culture determines the acceptable way of presenting oneself and for participating effectively in society (Hall, 1992). According to Martin \& Siehl (1983), cultures serve as organizational control mechanisms, informally approving or prohibiting some patterns of behavior. Likewise, Allaire \& Firsirotu (1984) suggest that one component of organizational culture is a "sociostructural system" that includes "formal goals and objectives, authority and power structure control mechanisms, reward and motivation, process of recruitment, selection and education, and sundry management processes" (p. 213). Roberts (2005) notes that the macrocontext for cross-cultural interactions are the organizational policies, structures, and norms. While Chreim, Williams, \& Hinings (2007) theorize that "In most professional fields, strongly institutionalized beliefs and values define professionalism” (p. 1517).

Organizations socialize employees to their culture. Ansari, Fiss, \& Zajac (2010) note that there is a 'preexisting cultural universe' that delineates roles, responsibilities, and the boundaries of appropriate behavior. The organizational socialization process maintains the organization's culture. Socialization impacts both the organization and its members. Pascale (1985) defines socialization as the, "systematic means by which firms bring new members into their culture...It encompasses the process of being made a member of a group, learning the ropes, and being taught how one must communicate and interact to get things done" (p. 27). When joining a new organization, “... newcomers often experience a sense of vulnerability and uncertainty as they seek to learn the culture of the organization and their roles in relation to other members, and to establish themselves as valued members" (Schaubroeck, Peng, \& Hannah, 2013, p. 1148). Individuals observe the attitudes and behaviors of others to understand what is acceptable in a given setting (Restubog, Zagencyzk, Bordia, Bordia, \& Chapman, 2015). During socialization, the role of positive interactions with peers is noted by Bravo, Peiro, Rodriguez, \& Whitely (2003), who found that relations with superiors and co-workers are important for newcomers to develop knowledge, skills and social networks critical for their present work situation and future opportunities. Socialization is more important now than in the past because individuals are more mobile (Bauer, Bodner, Erdogan, Truxillo, \& Tucker, 2007). Socialization is a more difficult process for some employees. Bauer et al. (2007) state that "newcomers transitioning from school to work face more drastic transitions and greater challenges than those transitioning from one job to another job" (p. 710).

Therefore, culture and socialization can foster sameness in employees, which often works against the goals of a diverse workforce. This concept is examined in the next section.

\section{Diversity Initiatives}

\section{Evolving Goals of Diversity Initiatives: From Demographic Representation to Diversity of Ideas}

Diversity continues to be a widely debated subject in the United States and throughout the western world. The concept has undergone significant changes over the last several years especially in business and industry. The business case for diversity in the workplace has shifted from being 
predominately regulatory to one of competitive advantage. This change in perspective has been largely attributed to the business community's recognition of the growing market of diverse customers, and the need to draw talent from an ever-diversifying employee pool. It has been decades since the concept of diversity was introduced into mainstream American lexicon. Originally viewed as purely external physical and demographic characteristics, the diversity discourse of today has expanded to include it's many and varied nuances such as, ethnicity, gender, race, national origin, disability, age, sexual orientation, religion, political affiliation, socioeconomic, and diversity of perspectives and ideas among others. Petriglieri (2011) distinguishes, “...between those (social identities) that are mostly ascribed or involuntary, such as gender or race, and those that are mostly achieved or voluntary" (p. 643).

Diversity benefits companies from a legal, business, customer and employee perspective. The concept of diversity, "... which began for many as an effort to meet governmental and legal requirements has evolved into a strategic priority aimed at positioning organizations more competitively in the marketplace" (Jayne \& Dipboye, 2004, p. 410). Herring (2009) states,

The politics surrounding diversity and inclusion have shifted dramatically over the past 50 years. Title VII of the 1964 Civil Rights Act makes it illegal for organizations to engage in employment practices that discriminate against employees on the basis of race, color, religion, sex, or national origin. This act mandates that employers provide equal employment opportunities to people with similar qualifications and accomplishments. By the late 1970s and into the 1980s, there was growing recognition within the private sector that these legal mandates, although necessary, were insufficient to effectively manage organizational diversity. Many companies and consulting firms soon began offering training programs aimed at 'valuing diversity.'...During the 1990s...Managing diversity became a business necessity, not only because of the nature of labor markets, but because a more diverse workforce was thought to produce better business results. Exploiting the nation's diversity was viewed as key to future prosperity. (pp. 209-210)

Jayne \& Dipboye (2004) suggest that competing for the best talent requires companies to recruit an increasingly diverse labor pool and that a global economy requires dealing with an increasingly diverse customer base. They also note, "demographic diversity unleashes creativity, innovation, and improved group problem solving, which in turn enhances the competitiveness of the organization" (Jayne \& Dipboye, 2004, p. 410). From a managerial perspective, Andrevski, Richard, Shaw, \& Ferrier (2014) state that diversity can help to increase market share and profits, and that

Greater managerial racial diversity provides favorable conditions for individuals with diverse knowledge bases to exchange knowledge and information, which in turn increases the capacity to recognize and exploit opportunities for new competitive actions. This capacity reduces the development costs and hastens the introduction of competitive actions. (p. 836)

The majority of large firms now offer diversity training to reduce prejudice and discrimination, improve attitudes toward diversity, develop skills for working with diverse populations, and build more respectful interpersonal interactions (Andrevski, et al., 2014; Bonaccio, O'Reilly, O'Sullivan, \& Chiocchio, 2016).

\section{Are Workplace Diversity Initiatives Achieving Their Intended Results?}

Diversity defined as demographic representation. Despite legal and business initiatives, 
inequality still exists. Research regarding the inconsistency of achieving desired results focuses on continuing gender and racial inequality, which undermine the values and goals of diversity. According to Tyler (2007), despite many gains in the workplace by minorities and women, both groups are still underrepresented in the upper ranks of corporate America. According to Murrell, Blake-Beard, Porter, \& Perkins-Williamson (2008),

While diversity in workforce participation is increasing, a glass ceiling still effectively keeps the top levels absent of the same diversity that exists throughout the middle and lower levels of organizations. The glass ceiling has been defined as an 'unseen, yet unbreachable barrier that keeps minorities and women from rising to the upper rungs of the corporate ladder, regardless of their qualifications or achievements'. (p. 276)

Sipe, Larson, McKay, \& Moss (2016) mention the 'glass cliff' in reference to an unsupportive environment when women do reach a position of leadership.

There is also disparity regarding earnings, especially at the higher earnings levels (Cotter, Hermsen, Ovadia, \& Vanneman, 2001; Acker, 1990). According to Joshi, Son, \& Roh (2015), "A particularly striking pattern in our findings is that, in highly prestigious occupations, women did not perform at lower levels than men, and yet men were rewarded significantly higher than women" (p. 1533).

Several authors report on the disparate demographic composition of upper management. Zarya (2016) reports there were 21 women CEOs in the Fortune 500. Fairchild (2014) reports there were 27 women CEOs in the Fortune 1000 and lists the most common college majors among women CEOs in the Fortune 1000; "Engineering (9 women), followed by Economics (7), Accounting (5) and Business (5)" (n.p.). It is interesting that the largest proportion of majors is in Engineering, typically a male dominated field. Wallace (2015), reports five Black CEOs at Fortune 500 companies. In 2015, DiversityInc. reported 10 Asian and 10 Latino Fortune 500 CEOs. Jones (2017), reported on Fortune.com, "Seventy-three percent of the senior executives, men and women, are white. The rest are $21 \%$ Asian, 3\% Latino, 2\% black, $0.6 \%$ two or more races, $0.2 \%$ Native American and $0.1 \%$ Native Hawaiian or Pacific Islander" (n.p.).

Continuing racial and gender disparity extends to corporate boards of directors (McDonald \& Westphal, 2013; Mizruchi, 2004; Palmer \& Barber, 2001). McDonald \& Westphal (2013) studied corporate boards of directors and found that,

In particular, while significant numbers of women and racial minorities have obtained initial board appointments, women and minorities are much less well represented among those who hold more than one corporate board seat...holders of multiple directorships tend to exercise disproportionate influence over corporate policy at each of the firms where they serve as a director... while women and minorities represented 28 percent and 22 percent, respectively, of those individuals who held one corporate board seat, they represented only 8 and 5 percent, respectively, of those who held multiple seats. (p. 1170)

Diversity defined as diversity of ideas. Roberts (2005) notes inconsistencies regarding implementing diversity initiatives. She found that "Even in demographically diverse organizations, individuals receive messages regarding the extent to which such diversity is welcomed into the 
organization's culture" (p. 699). There is a marked distinction between whether organizations view diversity as demographics, or whether diverse ideas and perspectives are truly valued. Roberts (2005) also notes,

There is a difference between... organizations that merely contain diversity and multicultural organizations that value diversity. The organizations that merely contain diversity generally adopt a 'discrimination and fairness' paradigm for managing diversity that is based on a colorblind philosophy: assimilation and conformity are expected, and employees are not invited to draw on their unique assets and perspectives... On the other end of the continuum some organizations adopt an integration and learning perspective: they enable employees to incorporate their perspectives into the core work of the organization by redefining market strategies, business practices, and organizational cultures. (p. 699)

Dwertmann, Nishii, \& van Knippenberg (2016) differentiate between a fairness and discrimination vs. a synergy perspective of diversity. The fairness and discrimination perspective operates mainly at the organization level, includes Human Resource practices, and focuses on preventing negative outcomes by ensuring equal employment opportunity in hiring and fair treatment once hired. In contrast, the synergy perspective operates at the unit level, and is characterized by; the extent to which individuals value and respect the viewpoints of others who are different from themselves, an inclusive climate, and an appreciation of diverse perspectives. These authors state, "This could suggest that a strong fairness \& discrimination climate would be a necessary but insufficient precondition for the synergetic effects of a strong synergy climate" (p. 1162). Simply hiring diverse individuals will not lead to synergy. Likewise, Bunderson \& Reagans (2011) note that diversity of team member "backgrounds and characteristics was not a good predictor of team decisions because of power and status differences" (p. 1191). This occurs when higher status members dominate the group.

Further, Zweigenhaft \& Domhoff (2006) offer another insight as to why demographic diversity may not result in a true diversity of ideas saying,

The new diversity within the power elite is transcended by common values... The newcomers to the power elite have found ways to signal that they are willing to join the game as it has always been played, assuring the old guard that they will call for no more than relatively minor adjustments, if that...Class backgrounds, current roles, and future aspirations are more powerful in shaping behavior in the power elite than gender, ethnicity, race or sexual orientation. (p. 7)

Jones (1986) writes, "In most organizations, conformity is an unwritten rule. If you don't conform, you can't be trusted-especially for higher positions" (p. 90).

\section{Cultural Mechanisms at Work}

\section{The Dysfunction of Cultural Bias, Group Favoritism, Disrespect, Unequal Social Influence and Stereotyping}

Cultural similarity. Culture operates at both the personal and organizational level. The impact of cultural similarities and differences external to the organization persist in their impact on professional opportunities in the work environment. Cultural similarity provides advantages for some employees. Similar cultural interests can create a better relationship with one's colleagues, as noted by DiMaggio 
(1987), and that shared cultural interests can include music and art. Further,

Taste, then, is a form of ritual identification and a means of constructing social relations (and of knowing what relationships need not be constructed). It helps to establish networks of trusting relations that facilitate group mobilization and the attainment of such social rewards as desirable spouses and prestigious jobs. (p. 443)

However, the opposite can be true for those who do not share the same cultural tastes as the power group.

Cultural bias. Cultural bias, that leads to self-selection bias, is yet another impediment that occurs when managers select those most like themselves for career opportunities to the exclusion of others. Elliot \& Smith (2004) wrote, "Finally, with respect to preferences for similar others, there are strong findings to indicate that most superiors, regardless of their race and sex, tend to fill power positions they oversee with ascriptively similar others" (p. 384). According to Rivera (2012), "Moreover, evaluators constructed and assessed merit in their own image, believing that culturally similar applicants were better candidates" (p. 1017). Elliot \& Smith (2004) state further that those already in power "have greater opportunity to exercise this self-similar preference and, in the process, reproduce their advantage over successive generations of employees" (p. 384).

Group favoritism. Other issues include group favoritism, which implies that those in the "ingroup" have an advantage over those who are outside the group (Bell, 2007; Brewer, 1999; Chung, Laio, Jackson, Subramony, Colakoglu, \& Jiang, 2015), and that group favoritism works against the goals of diversity (Cox \& Blake, 1991). Brewer (1999) states that "in-group bias and intergroup discrimination is motivated by preferential treatment of in-group members rather than direct hostility toward outgroup members" (p. 429). For example, Bell (2007) states,

A likely result of in-group favoritism in a work setting is the hiring, promoting, and rewarding of those in power (i.e., the dominant group) of members of their in-group. Even if no overt derogation of out-group members is involved, the non-dominant out-group is disadvantaged when the dominant in-group is favored. (p. 45)

"Outsiders, or people treated as outsiders (no matter how talented or well-trained), rarely do as well" (Jones, 1986, p. 89).

Disrespect. Also, while overt discrimination does occur, more subtle forms do exist. Cortina, Kabat-Farr, Leskinen, Huerta, \& Magley (2013) note that selective incivility is a form of modern discrimination in organizations, which is described as behaviors that "are characteristically rude and discourteous, displaying a lack of regard for others" (p. 1580). The uncivil behavior "may sometimes represent a covert manifestation of gender and racial bias when women and people of color are selectively targeted" (p. 1581). Further, "Individuals targeted with uncivil work behavior report greater job-related stress, distraction, and dissatisfaction; lower creativity and cooperation; and greater psychological distress. Over time, they lose commitment to their organizations and quit at higher rates" (p. 1580). These factors all have financial costs for employers. As noted by Cortina et al. (2013), "Leaders should stress that unacceptable discrimination includes not just overt expressions of misogyny and bigotry but also subtle acts of disrespect" (p. 1600).

Unequal social influence. Castilla (2011) writes that socially connected managers have greater 
opportunities to share their impressions of employees, and "the impact of such interactions among managers is significantly magnified by managerial demographic similarity" (p. 687). Further,

Ultimately, these managerial mechanisms have the potential to operate at many stages of an employee's career (not just performance appraisals, but also pay, training and career possibilities, and work assignments) and thus can help explain how stratification is sustained in the workplace, as managers' social context affects their assessments of employees below them. (p. 688)

Stereotyping. Barriers in the workplace have also been attributed to stereotyping (Fiske \& Taylor, 2008; Roberts, 2005). Fiske \& Taylor (2008) provide the following definition, "Stereotyping is the cognitive aspect of bias - most frequently studied for gender, race and age - and it comes in both blatant and subtle forms, a difference that matters in both practical and theoretical terms" (p. 308). Unfavorable stereotypes can detract from one's image (Roberts, 2005), and impacts perceptions regarding a candidate's abilities (Lee, Pitesa, Thau, \& Pillutla, 2015). Further, stereotyping leads people to interpret information and events to fit their expectations (Fiske \& Taylor, 2008; Tetlock, 1983). This is very relevant to career advancement because behaviors of stereotyped individuals will be better remembered if they conform to the stereotype than if they deviate from it (Srull \& Wyer, 1989, p. 79). Regarding perception, Westphal \& Stern (2007) found that "people are more cynical in interpreting the behavior of dissimilar others" (p. 273).

Arguably, business organizations have made significant progress in combating discrimination based on physical characteristics, but have been less successful confronting discrimination based on behavioral manifestations of culture. The result is that in many organizations, cultural barriers still exist with regard to hiring and career advancement.

\section{Organizational Culture Impacts Hiring}

Organizational culture within the work environment impacts hiring, and cultural similarity outside of the work environment also has an impact. According to Rivera (2012), "Hiring practices are gatekeeping mechanisms that facilitate career opportunities for some groups, while blocking entry for others" (p. 1000). Historically, this is a continuing issue, as Rivera (2012) adds,

Early scholars, including Weber (1958) and Veblen (1899), argued that similarities in leisure pursuits, experiences, self-presentation, and other 'lifestyle markers' serve as badges of group membership and bases of inclusion or exclusion from desirable social opportunities. In fact, Weber suggested that lifestyle markers are fundamental bases of status group reproduction and social closure. (p. 1001)

In 1949, Blake \& Harriman found,

A recent survey of the consideration of certain characteristics of candidates for junior executive positions in industry seems to indicate that too much dependence is still placed on subjective judgments to make the process of selection very trustworthy. In the areas of the candidate's home and family relationships, personality traits, moral background, social relationships and early background, little use was made of objective techniques even as a check on the judgment of the interviewer. (p. 30) 
Research studies found that cultural fit is important criteria for hiring decisions (Cable \& Judge, 1997; Rivera, 2012), and can work against students with diverse backgrounds. According to Rivera (2012), a study of hiring practices at elite professional service firms found that cultural similarities were "the most common mechanism employers used to assess applicants at the job interview stage" (p. 1006). Further, "Evaluators who believed a common personality characterized employees in their firm frequently looked for candidates who fit this image...In essence, firms sought surface-level (i.e., demographic) diversity in applicant pools but deep-level (i.e., cultural) homogeneity in new hires" (pp. 1008-1009). According to Rivera (2012),

The fate of students with similar credentials in the competition for elite jobs was linked to their display of cultural signals; applicants whose experiences, leisure pursuits, and self- presentation styles matched those of employers could cash in these cultural similarities for jobs offering double to quadruple the salaries earned by other graduates from the same schools and for admission to a prestigious occupational group that serves as a gateway to the contemporary U.S. economic elite. (p. 1017)

These cultural signals have important socioeconomic dimensions. Rivera (2012) adds,

Moreover, evaluators tended to favor extracurricular activities associated with the white uppermiddle class and that were acquired through intense, prolonged investment of material and temporal resources not only by job applicants but also by their parents ...the types of cultural similarities valued in elite firms' hiring processes had the potential to create inequalities in access to elite jobs based on parental socioeconomic status. (p. 1017)

Other authors note disparities experienced by diverse job seekers. According to Sangganjanavanich, Lenz, \& Cavazos (2011),

All of the participants suggested that lack of familiarity with the U.S. culture impeded their ability to compete with their domestic counterparts. They reported struggling to manage their cultural backgrounds and cultural expectations in the United States. Although these differences were present throughout the employment seeking process, they were most obvious during job interviews. These differences influenced communication styles and behaviors, including nonverbal communication (e.g., how to conduct oneself during an interview and what are culturally appropriate and accepted behaviors) and verbal communication (e.g., what to share and how much information to share). (p. 21)

The bias appears to begin before interviewers meet prospective job candidates, through "preinterview impressions" (Dougherty, Turban, \& Callender, 1994, p. 659). Dougherty et al. (1994) state,

Behavioral biases...involve interviewers' behaving in a fashion that confirms their first impressions of applicants. Interviewers, for example, may display a sense of 'positive regard' or 'negative regard' toward applicants based on their initial evaluations. Applicants may then respond in a manner consistent with the interviewers' positive or negative behavior. Cognitive biases also occur if interviewers distort information to support first impressions, using selective attention and recall of information. This sequence of behavioral and cognitive biases produces a self-fulfilling prophecy. (p. 659) 


\section{Organizational Culture Impacts Career Advancement}

Individuals who are successfully socialized into an organization's culture have better prospects for advancement. In their study of workplace ostracism, Robinson, O'Reilly, \& Wang (2013) found that inadvertent ostracism may occur when members of a group, department, or entire organization have different understandings of what is socially appropriate behavior.

Roberts (2005) writes, "Nonverbal cues (e.g., appearance, dress, displayed emotion), verbal disclosures (e.g., information about the self), and actions (e.g., performance, citizenship) shape others' perceptions of one's competence, character, and ability to meet the cultural standards of professional behavior" (p. 688). According to Bunderson \& Reagans (2011),

Individuals come to assign status value to different member characteristics through exposure to the dominant values and beliefs within the broader society, and they then import those beliefs into their interactions with others in a group setting. As a result, group members with societally disadvantaged status characteristics tend to occupy lower positions within the social hierarchy of the groups they join, which results in fewer opportunities for involvement, participation, and influence - regardless of whether they possess unique or even superior knowledge, perspective, or insight. (p. 1185)

Likewise, Gray, \& Kish-Gephart (2013) state that social class differences manifest themselves in society and organizations through behaviors and attitudes, and further, that class differences carry performance expectations such that "...lower class individuals will be judged to be less competent than higher class ones (simply because of their social class)" (p. 673).

Individuals new to the workforce from diverse populations face additional challenges. Jamison (2010) states,

It is generally recognized that many business students lack 'soft skills' that are necessary for success. This is particularly true of business students from economically and socially disadvantaged backgrounds. First generation college students and students from 'working class' backgrounds often begin their careers in business without exposure to the norms and expectations of professional or corporate culture. The intricacies of American corporate culture, and particularly the 'soft skills' needed to survive and thrive in a business environment, are foreign to them. Technical business courses do not adequately emphasize 'soft skills' such as resume writing, business ethics, team building, interview skills, leadership, group dynamics and business etiquette. (p. 102)

This is more difficult for students who are the first in their family to attend college (Pike \& Kuh, 2005; Mangan, 2015).

New employees who inadvertently create a negative first impression and face rejection at the outset, could have decreased opportunities for advancement. According to McDonald \& Westphal (2013), people evaluate new group members on the basis of first impressions, and interpret subsequent behavior based on these first impressions (p. 1174). These impressions may be self-perpetuating, since the manner in which employees are treated can impact their attitudes and performance (Chen, Ferris, Kwan, Yan, Zhou, \& Hong, 2013; Tesser, 2000). 
Several authors have cautioned about the impact of negative workplace environments. Employees subjected to immediately damaging negative workplace behaviors are more likely to resign in the short term, while targets of undermining behaviors may eventually resign but only after the behaviors have taken their toll (Duffy, Ganster \& Pagon, 2002). Negative feelings include greater anger and tension (Baron, 1988).

Groups who are excluded are at a disadvantage. They do not have the advantage of social (network) resources that benefit employees "as a universal mediating variable between family background, ability, cultural capital, and communicative competence, on one side, and 'outcomes' on the other" (Bridges \& Villemez, 1986, p. 574). Elliot \& Smith (2004) note that inequality in workplace power results when women and minorities are excluded from networks since much of job training and career development comes from informal instruction. Eagly \& Carli (2007) state,

Perhaps the most destructive result of the work/family balancing act so many women must perform is that it leaves very little time for socializing with colleagues and building professional networks. The social capital that accrues from such 'nonessential' parts of work turns out to be quite essential indeed. (p. 68)

\section{The Role of Management to Address Organizational Culture}

\section{Valuing Diversity}

Research reveals actions that companies can take to achieve the benefits of a diverse workforce and ensure an environment where people are valued and respected with equal opportunities for advancement. Policies and practices for recruiting, screening, hiring, orientation, training, compensation, performance management, and career advancement must support the organization being one that 'values diversity' rather than one that merely 'contains diversity' (Roberts, 2005). The organization must ensure that actual practices follow intended policies.

It is well settled that without managerial support, even the best diversity initiatives are destined for mediocrity. This assessment can partially explain disparate results. Managerial values supportive of employees increased both the likelihood of adopting diversity programs and their effectiveness (Herdman \& McMillan-Capehart, 2010).

Climate is an important aspect for management focus on since, "A positive relational climate is characterized by factors such as mutual respect among employees, relational coordination, interdependence and shared social values" (Ashforth, Schinoff, \& Rogers, 2016, p. 4). Creating a supportive diversity climate is likely to promote loyal behavior in employees (Chung et al., 2015), encourage the exchange and integration of diverse information (Dwertmann, et al., 2016), and promote a climate of cooperation, communication, and information sharing (Seong, Kristof-Brown, Park, Hong, \& Shin, 2015).

According to Kammeyer-Mueller, Wanberg, Rubenstein, \& Song (2013), "Such an initially supportive attitude may foster feelings of confidence in the newcomer, which will encourage him/her to reciprocate this positive social interaction in the form of increased proactive socialization" (p. 1109). 
However, these authors note,

Undermining a newcomer, especially in the initial weeks of work, will send a strong signal that he or she is not welcome... and provides negative feedback to the newcomer about his or her fit with a work group and an organization... and will therefore dampen the newcomer's motivation to proactively engage her/his environment. Under these conditions, it is likely that the newcomer will reciprocate these overt efforts to exclude or undermine his or her position by withdrawing from the work group and engaging in fewer proactive efforts to fit in. (p. 1109)

Providing an environment of psychological safety has also been cited as a component impacting organizational success. Psychological safety includes a belief that others will not reject people for being themselves, that team members care about and are interested in each other as people, other members have positive intentions, and team members respect each other's competence (Edmondson, 1999). Psychological safety is a catalyst to learning behaviors which impact organizational performance (Carmeli, Brueller, \& Dutton, 2009; Edmondson, 1999), make it possible "for diverse groups to engage in integrative decision-making processes" (Dwertmann et al., 2016), and increase one's capacity to take advantage of opportunities (Dutton, Roberts, \& Bednar, 2010). Without high levels of career and psychosocial support from within one's own organization, individuals are likely to feel less confident that they are valued for their own abilities, thus decreasing their sense of potential (Higgins \& Kram, 2001, p. 281).

If done correctly, social experiences and "socially embedded resources" such as positive interpersonal relationships increase employees' sense of competence (Roberts, Dutton, Spreitzer, Heaphy, \& Quinn, 2005, p. 730). If not done correctly, the impact is that the goals of a diverse workforce are not achieved, which makes individuals feel alienated and encourages them to withdraw from the organization. Individuals who perceive themselves as powerless may feel frustration, anxiety, and psychological withdrawal from work (Gilbert \& Ivancevich, 1999), and will feel less psychologically safe in work relationships (Creary, Caza, \& Roberts, 2015).

Ely \& Thomas (2001) support these previously mentioned findings stating,

We found that the perspective on diversity a group of people held, influenced how they expressed and managed tensions related to diversity, whether those traditionally underrepresented in the organization felt respected and valued by their colleagues, and how people valued and expressed themselves as members of their cultural identity groups; these, in turn, influenced people's sense of self-efficacy and work group functioning. (p. 260)

Seong et al. (2015) also note that, "Our findings suggest that it is possible to take full advantage of demographic diversity by emphasizing shared values as well as informational diversity as determinants of team compatibility" (p. 1205).

Regarding the building of an egalitarian work environment, Sipe et al. (2016) state that "management must be involved in communicating this value and building awareness among employees" (p. 245). Several authors have examined the value of social resources. Dutton, et al. (2010) write that social resources, including social support, mentoring, psychological safety, and attachments at work, “...strengthen individuals at work, increasing their capacity to deal with adversity and/or increasing their 
capacity to take advantage of opportunities" (p. 276).

\section{Management Initiatives}

A number of specific initiatives appear in literature to both promote diversity values and better educate employees about business culture and etiquette. Management can provide opportunities for networking, since networking can greatly enhance an employee's opportunities for advancement (Combs, 2003; Elliot \& Smith, 2004; Wolff \& Moser, 2009). In addition to resources and information, Podolny \& Baron (1997) state that social networks also provide a sense of belonging and an understanding of what is expected of individuals.

In a study reviewing the lack of women in leadership positions, Hoobler, Lemmon, \& Wayne (2014) state,

Summarizing these implications, it seems that formal organizational career management, such as accumulating training and development and challenging work assignments, and interpersonal support, such as manager career encouragement, are effective in pushing middle managers to climb the next rung on the organizational ladder. (p. 721)

Other authors have cited the following as initiatives that management can implement; mentoring (Murrell, et al., 2008; Tyler 2007; Ragins \& Kram, 2007); coaching (Edmondson, 1999), developing highquality peer and leader relationships (Schaubroeck, et al., 2013), social support (Dutton, et al., 2010), social acceptance (Bauer, et al., 2007), better understanding of non-verbal behavior and customs (Bonaccio et al., 2016), and newcomer onboarding and orientation (Kammeyer-Mueller et al., 2013). Regarding new employee socialization, Bauer, et al. (2007) state,

Organizations should consider the types of adjustment (role clarity self-efficacy, and social acceptance) as key indicators of newcomer socialization. To the degree that they can facilitate newcomers in achieving higher levels of each of these, they should see improved job attitudes and performance. Although turnover has many potential antecedents, more successful adjustment appears to help increase intentions to remain and decrease turnover. (p. 717)

Studies show that mentors and mentoring programs are highly effective. "Mentoring programs not only create opportunities for all people, but change behaviors at the senior-executive level" (Hardy, 1998, p. S11). Murrell at. al (2008) note that formal mentoring programs are structured programs sponsored and managed by the organization. Informal mentoring is grown out of social relationships. Humberd \& Rouse (2016) state there are two traditional functions of mentoring; career and psychosocial. They note, "Career functions include sponsorship, exposure and visibility, coaching protection and challenging assignments. Psychosocial functions include role modeling, acceptance and confirmation, counseling and friendship" (p. 437). As noted by Ragins \& Kram (2007), “...career-related mentoring was positively related to career outcomes, including compensation, salary growth, promotions, career satisfaction, job satisfaction and satisfaction with the mentor" (p. 53).

The glass ceiling, generally defined, is a barrier through which the next stage or level of advancement can be seen, but cannot be reached by a section of qualified and deserving employees. This represents yet another challenge that disparately impacts women and underrepresented minorities. The Federal Glass Ceiling Commission (1995) identified seven elements of comprehensive, systemic business 
practices to effectively break the glass ceiling. These exemplary practices include;

Leadership and career development; rotation/nontraditional employment; mentoring; accountability programs; succession planning; workforce diversity initiatives; and family friendly programs. Taken together, these elements comprise a corporate 'best practices' agenda that must become standard practice. Key to the success of these efforts is the active support of corporate leadership, whose commitment will change the corporate culture. (p. 18).

\section{The Role of Educational Institutions to Teach Organizational Culture}

While businesses work to 'value diversity' (Roberts 2005), individuals should make best efforts to fully understand the business culture and business etiquette of their respective fields. Knowledge of business etiquette and business culture has been shown to be a determinant of success in the workplace. Educational institutions can work to ensure that students are better prepared for reaching their career aspirations in the business world. According to Roberts (2005), "In a diverse society, all organizational members must learn how to effectively navigate their interactions with people from different cultural backgrounds so that they can build credibility, form high-quality relationships, and generate high performance outcomes with their constituents" (p. 685).

\section{Challenges Faced by Diverse Students}

According to Tate, Caperton, Kaiser, Pruitt, White, \& Hall (2015), "First-generation college students represent a large proportion of individuals seeking higher education in the United States; yet this population does not perform as well academically as, and persist to graduation at lower rates than, their peers who have more familial context for the college-going experience" (p. 294).

According to Mangan (2015),

The challenges these students face are daunting. First generation students tend to work longer hours at their jobs, are less likely to live on campus, and are more likely to have parents who would struggle to complete financial aid forms. They're also more likely to arrive academically unprepared for the rigors of college and to require remediation before they can start earning college credit. Many feel the tug of family responsibilities, rushing home after class to take care of younger siblings or missing classes to care for an ailing grandparent. (p. A4)

She notes that more than $28 \%$ of the 800,000 students who filled out the college Common Application last year reported that they were first generation students (p. A4). Finally, Sipe et al. (2016) state that raising awareness "should be considered the first step necessary to then educate or train students how to effectively handle potential incidents of workplace discrimination” (pp. 235-236).

Zhang, Xia, Fan, \& Zhu (2016) note the increased presence of international students, especially in the business schools. Culturally and linguistically diverse international students, compared to domestic students have unique social, cultural and academic challenges. Zhang et al. (2016) state that peer mentoring programs can "facilitate social, psychological, cultural and academic adjustment of international students" (p. 372). 


\section{Curriculum Topics: Business Culture and Business Etiquette}

Just as Roberts (2005) differentiates between companies that 'contain' diversity vs. 'value' diversity, Lee, Williams, \& Kilaberia (2012) differentiate between 'structural diversity' (demographics) and 'curricular diversity' (diverse ideas), in reference to higher education. According to Zhang et al. (2016), "But there is difference between knowing about diversity and being able to deal with diversity. Being aware of diversity is not much help, unless students can skillfully put diversity knowledge to practice in cross-cultural interaction" (p. 371). Also,

In shifting the focus of diversity from differences to responsive strategies, the aim of diversity education on campus is to teach students the effective strategies of positive intergroup interactions. As such, diversity management is a proactive way to enable all student groups to reach their full potential in pursuit of objectives, and is more than just a passive remedy to reduce prejudice, discrimination, and conflicts. (p. 370)

According to Hanassab (2006), "A critical challenge for every college and university is to educate its diverse student population so that they are multiculturally competent and can successfully function in America's pluralistic society" (p. 159).

It is critical for business education programs to include the role of non-verbal behavior within business culture and business etiquette. Non-verbal behaviors include; facial expressions, gestures, posture, attire, eye contact, voice qualities, personal space, personal grooming and even silence. Bonaccio et al. (2016) demonstrated that nonverbal behaviors convey social information such as competence, prestige and persuasion. It is important to recognize there are differences among cultures. Bonaccio et al. (2016) state, "Yet some important cross-cultural differences do exist and they likely influence leadership effectiveness. The same nonverbal behavior can be interpreted or valued differently across cultures" (p. 1060).

Educational institutions may better prepare first generation students for success by offering supplementary programs. Pike \& Kuh (2005) note the special needs of first-generation students attending college and state,

Workshops for advisors and others who may work closely with first-generation students should address issues that may be particularly relevant to this group; at the least, advisors should know who among their advisees are the first in their family to go to college and should discuss on multiple occasions how students can get involved in activities inside and outside the class-room that will increase their overall level of engagement with learning resources and that will promote greater social and academic integration. (p. 291)

The role of internships is important for the success of students leaving institutions and entering into the workforce. According to Barnett (2012), her findings have,

Important implications for business school curriculums and career development programs, for staff and faculty alike. The current study indicates that the internship serves as a means for students to develop realistic expectations about work likely to, in turn, ease their transition from business student to career professional. Career development staff and faculty should take a more proactive role in encouraging business students to complete internships or, even, requiring the internship as 
part of the business curriculum. (p. 283)

Jamison (2010) notes a program within a business curriculum at South Carolina State University which "...addresses the challenges of promoting soft skills within the context of a typical business curriculum and offers insights into the challenges and achievements of the program" (p. 102). The program is "...designed to develop core skill sets that are necessary for career success. These skill sets include (1) employability skills; (2) business protocol; (3) business communication and technological competency; and (4) leadership development" (p. 104). Jamison (2010) states,

Students are required to follow codes of dress and conduct that are meant to reinforce the importance of professional decorum in United States business culture. The dress code mandates style and color of clothing for males and females. Conduct codes mandate appropriate behavior during the presentation including the preferred method of asking questions and identifying oneself to the speaker (p. 106).

White (2009) likewise describes the Leadership and Professional Development (LPD) course at Morehouse College which,

Has two purposes: (a) develop skill sets that include personal leadership (values, ethics, and goal setting), personal management (business decorum skills), and interpersonal leadership (teamwork and civic responsibility) and (b) expose students to the intricacies and nuances of organizational life (corporate culture), with special emphasis on the influence of being African American in corporate America. (p. 72)

The Federal Glass Ceiling Commission (1995) states,

By educating students about the different values, cultures, history, styles of communicating, dress, food, family customs, and other group norms, schools can better prepare future executives to function comfortably and collaboratively with peers and subordinates from diverse ethnic and racial groups. Therefore, the Commission recommends that cultural awareness education become part of every school's curriculum so that children can experience, understand and value the strengths that diversity can create. (p. 49).

\section{Conclusion}

As previously noted, manifestations of cultural diversity go far beyond the "physical characteristics' of gender, race, national origin, color, and religion. Research reveals that the complex and deeply layered expressions of diversity also include 'learned' characteristics such as communication style and preferences, manner of dress, and a host of other well documented facets. Moreover, the growing body of recent research strengthens the premise that workplace diversity continues to be a significant driver in the outcomes of the corporate workplace. While organizations benefit when managers truly understand the value of diversity, individuals climbing the corporate ladder, will also benefit from deciphering the unwritten rules of business etiquette and organizational culture. Employees who ignore or underestimate the power of the values, norms, and behaviors of their business environment do so at their professional peril. All too often, the failure of educational institutions to 'soft skill' educate, the failure of management to appropriately address employee shortcomings and support corrective behaviors, and the failure of employees to recognize the sometimes-subtle norms and expectations of professional or 
corporate culture, create the perfect milieu for unhealthy conflict. Such discord in the workplace often leads to disengagement and even finds its way to the courthouse steps in the form of a lawsuit for perceived discrimination. Both business organizations and institutions of higher education can prevent this course of action and increase the candidates' and organizations' chances for professional success by properly implementing diversity training and education. When candidates are prepared to recognize the intricacies of organizational culture and business etiquette in college, and armed with the candid feedback, support and knowledge from their supervisors, their chances for professional success will increase exponentially.

\section{References}

Acker, J. (1990). Hierarchies, jobs, bodies: A theory of gendered organizations. Gender and Society, 4 , $139-158$.

Allaire, Y., \& Firsirotu, M. E. (1984). Theories of organizational culture. Organization Studies, 5, 193226.

Andrevski, G., Richard, O. C., Shaw, J. D., \& Ferrier, W. J. (2014). Racial diversity and firm performance the mediating role of competitive intensity. Journal of Management, 40, 820-844.

Ansari, S. M., Fiss, P. C., \& Zajac, E. J. (2010). Made to fit: How practices vary as they diffuse. Academy of Management Review, 35, 67-92.

Ashforth, B. E., Schinoff, B. S., \& Rogers, K. M. (2016). "I identify with her." "I identify with him": Unpacking the dynamics of personal identification in organizations. Academy of Management Review, 41, 28-60.

Baron, R. A. (1988). Negative effects of destructive criticism: Impact on conflict, self-efficacy, and task performance. Journal of Applied Psychology, 73, 199- 207.

Barnett, K. (2012). Student interns' socially constructed work realities: Narrowing the work expectationreality gap. Business Communication Quarterly, 75, 271-290.

Bauer, T. N., Bodner, T., Erdogan, B., Truxillo, D. M., \& Tucker, J. S. (2007). Newcomer adjustment during organizational socialization: A meta-analytic review of antecedents, outcomes, and methods. Journal of Applied Psychology, 92, 707-721.

Bell, M. P. (2007). Diversity in organizations. Mason, OH: Thomson South-Western.

Blake, W. D., \& Harriman, A. E. (1949). The selection and training of executives. The Journal of Social Psychology, 29, $29-35$.

Boas, F. (1938). The Mind of Primitive Man. Retrieved from https://archive.org/details/mindofprimitivem031738mbp. The Macmillan Company. Book contributor: Osmania University Collection: universallibrary.

Bonaccio, S., O’Reilly, J., O’Sullivan, S. L., \& Chiocchio, F. (2016). Nonverbal behavior and communication in the workplace: A review and an agenda for research. Journal of Management, 42, 1044-1074. 
Organizational Culture and Impact on Business Opportunities and Advancement

Bravo, M. J., Peiró, J. M., Rodriguez, I., \& Whitely, W. T. (2003). Social antecedents of the role stress and career-enhancing strategies of newcomers to organizations: A longitudinal study. Work \& Stress, $17,195-217$.

Brewer, M. B. (1999). The psychology of prejudice: Ingroup love or outgroup hate? Journal of Social Issues, 55, 429-444.

Bridges, W. P. \& Villemez, W. J. (1986). Informal hiring and income in the labor market. American Sociological Review, 51, 574-82.

Bunderson, J. S., \& Reagans, R. E. (2011). Power, status, and learning in organizations. Organization Science, 22, 1182-1194.

Cable, D. M., \& Judge T. A. (1997). Interviewer's perceptions of person-organization fit and organizational selection decisions. Journal of Applied Psychology, 82, 546-561.

Carmeli, A., Brueller, D., \& Dutton, J. E. (2009). Learning behaviours in the workplace: The role of highquality interpersonal relationships and psychological safety. Systems Research and Behavioral Science, 26, 81-98.

Castilla, E. J. (2011). Bringing managers back in: Managerial influences on workplace inequality. American Sociological Review, 76, 667-694.

Chen, Y., Ferris, D. L., Kwan, H. K., Yan, M., Zhou, M., \& Hong, Y. (2013). Self-love's lost labor: A self-enhancement model of workplace incivility. Academy of Management Journal, 56, 1199-1219.

Chreim, S., Williams, B. E., \& Hinings C. R. (2007). Interlevel influences on the reconstruction of professional role identity. Academy of Management Journal, 50, 1515 - 1539.

Chung, Y., Liao, H., Jackson, S. E., Subramony, M., Colakoglu, S., \& Jiang, Y. (2015). Cracking but not breaking: Joint effects of faultline strength and diversity climate on loyal behavior. Academy of Management Journal, 58, 1495-1515.

Combs, G. M. (2003). The duality of race and gender for managerial African American women: Implications of informal social networks on career advancement. Human Resource Development Review, 2, 385-405.

Cortina, L. M., Kabat-Farr, D., Leskinen, E. A., Huerta, M., \& Magley, V. J. (2013). Selective incivility as modern discrimination in organizations: Evidence and impact. Journal of Management, 39, 15791605.

Cotter, D. A., Hermsen, J. M., Ovadia, S., \& Vanneman, R. (2001). The glass ceiling effect. Social Forces, 80, 655-682.

Cox, T. H., \& Blake, S. (1991). Managing cultural diversity: Implications for organizational 
Organizational Culture and Impact on Business Opportunities and Advancement

competitiveness. Academy of Management Executive, 5, 45-56.

Creary, S. J., Caza, B. B. \& Roberts, L. M. (2015). Out of the box? How managing a subordinate's multiple identities affects the quality of a manager-subordinate relationship. Academy of Management Review, 40, 538-562.

Daniels, M. A. \& Greguras, G. J. (2014). Exploring the nature of power distance: Implications for microand macro-level theories, processes and outcomes. Journal of Management, 40, 1201-1229.

DiMaggio, P. (1987). Classification in art. American Sociological Review, 52, 440-455.

DiversityInc. (2015). McDonald's CEO to Retire; Black Fortune 500 CEOs Decline by 33\% in Past Year. Retrieved from http://www.diversityinc.com/leadership/mcdonalds-ceo-retire-black-fortune-500ceos-decline-33-past-year/, accessed July 14, 2016.

Dougherty, T. W., Turban, D. B., \& Callender, J. C. (1994). Confirming first impressions in the employment interview: A field study of interviewer behavior. Journal of Applied Psychology, 79, 659-665.

Duffy, M. K., Ganster, D. C., \& Pagon, M. (2002). Social undermining in the workplace. Academy of Management Journal, 45, 331-351.

Dutton, J. E., Roberts, L. M., \& Bednar, J. (2010). Pathways for positive identity construction at work: Four types of positive identity and the building of social resources. Academy of Management Review, 35, 265-293.

Dwertmann, D. J., Nishii, L. H., \& van Knippenberg, D. (2016). Disentangling the Fairness \& Discrimination and Synergy Perspectives on Diversity Climate Moving the Field Forward. Journal of Management, 42, 1136-1168.

Eagly, A. H., \& Carli, L. L. (2007). Women and the labyrinth of leadership. Harvard Business Review, 85(9), 62-71.

Edmondson, A. (1999). Psychological safety and learning behavior in work teams. Administrative Science Quarterly, 44, 350-383.

Elliot, J. R., \& Smith, R. A. (2004). Race, gender and work place power. American Sociological Review, 69, 365-386.

Ely, R., \& Thomas, D. (2001). Cultural diversity at work: The effects of diversity perspectives on work group processes and outcomes. Administrative Science Quarterly, 46, 229-273.

Fairchild, C. (2014). Women CEOs in the Fortune 1000: By the numbers. Fortune. Retrieved from http://fortune.com/2014/07/08/women-ceos-fortune-500-1000/, accessed August 9, 2014.

Federal Glass Ceiling Commission. (1995). Good for business: Making full use of the nation's human capital. Washington, DC: U.S. Department of Labor. 
Organizational Culture and Impact on Business Opportunities and Advancement

Fiske, S. T., \& Taylor, S. E. (2008). Social cognition: From brains to culture. New York: McGraw-Hill.

Gilbert, J. A., \& Ivancevich, J. M. (1999). A re-examination of organizational commitment. Journal of Social Behavior and Personality, 14, 385-396.

Goodenough, W. H. (2003). In pursuit of culture. Annual Review of Anthropology, 32, 1-12.

Gray, B., \& Kish-Gephart, J. J. (2013). Encountering social class differences at work: How "class work" perpetuates inequality. Academy of Management Review, 38, 670-699.

Hall, P. A. (1992). Peanuts: A note on intercultural communication. Journal of Academic Librarianship, 18, 211-213.

Hanassab, S. (2006). Diversity, International students, and perceived discrimination: Implications for educators and counselors. Journal of Studies in International Education, 10, 157-172.

Hardy, L. C. (1998). Mentoring: A long-term approach to diversity. HR Focus, 75(7), S11.

Herdman, A. O., \& McMillan-Capehart, A. (2010). Establishing a diversity program is not enough: Exploring the determinants of diversity climate. Journal of Business and Psychology, 25, 39-53.

Herring, C. (2009). Does diversity pay? Race, gender and the business case for diversity. American Sociological Review, 74, 208-224.

Higgins, M., \& Kram, K. (2001). Reconceptualizing mentoring at work: A developmental network perspective. Academy of Management Review, 26, 264-288.

Hoobler, J. M., Lemmon, G., \& Wayne, S. J. (2014). Women's managerial aspirations: An organizational development perspective. Journal of Management, 40, 703-730.

Humberd, B. K. \& Rouse E. D. (2016). Seeing you in me and me in you: Personal identification in the phases of mentoring relationships. Academy of Management Review, 41, 435-455.

Jamison, D. (2010). Leadership and professional development: An integral part of the business curriculum. Business Education Innovation Journal, 2(2), 102-111.

Jayne, M. E. A. \& Dipboye, R. L. (2004). Leveraging diversity to improve business performance: Research findings and recommendations for organizations. Human Resource Management, 43, 409424.

Jones, E. W., Jr. (1986). Black managers; The dream deferred. Harvard Business Review, 64(3), 84-93.

Jones, S. (2017). White Men Account for $72 \%$ of Corporate Leadership at 16 of the Fortune 500 Companies. Fortune. Retrieved from http://fortune.com/2017/06/09/white-men-seniorexecutives-fortune-500-companies-diversity-data/ accessed February 24, 2018. 
Organizational Culture and Impact on Business Opportunities and Advancement

Joshi, A., Son, J., \& Roh, H. (2015). When can women close the gap? A meta-analytic test of sex differences in performance and rewards. Academy of Management Journal, 58, 1516-1545.

Kammeyer-Mueller, J., Wanberg, C., Rubenstein, A., \& Song Z. (2013). Support, undermining, and newcomer socialization: Fitting in during the first 90 Days. Academy of Management Journal, 56, 1104-1124.

Lee, A., Williams, R., \& Kilaberia, R. (2012). Engaging diversity in first-year college classrooms. Innovative Higher Education, 37, 199-213.

Lee, S. Y., Pitesa, M., Thau, S., \& Pillutla, M. M. (2015). Discrimination in selection decisions: Integrating stereotype fit and interdependence theories. Academy of Management Journal, 58, 789-812.

Mangan K. (2015). The challenge of the first generation students. The Chronicle of Higher Education. May 22, 2015. Vol LXI(36), A4-A6.

Martin, J., \& Siehl, C. (1983). Organizational culture and counterculture: An uneasy symbiosis. Organizational Dynamics, 12, 52-64.

McDonald, M. L. \& Westphal, J. D. (2013). Access denied: Low mentoring of women and minority firsttime directors and its negative effects on appointments to additional boards. Academy of Management Journal, 56, 1169-1198.

Mead, Margaret, Editor, (1937). Cooperation and Competition Among Primitive Peoples. Retrieved from https://archive.org/details/cooperationandco033408mbp. McGraw Hill Book Company Inc. Book contributor: Osmania University Collection: universallibrary.

Mizruchi, M. S. (2004). Berle and Means revisited: The governance and power of large U.S. corporations. Theory and Society, 33, 579-617.

Murrell, A. J., Blake-Beard S., Porter D. M., Jr., \& Perkins-Williamson, A. (2008). Interorganizational formal mentoring: Breaking the concrete ceiling sometimes requires support from the outside. Human Resource Management, 47, 275-294.

Ouchi, W. G., \& Wilkins, A. L. (1985). Organizational culture. Annual Review of Sociology, 11, 457-483.

Palmer, D., \& Barber, B. M. (2001). Challengers, elites, and owning families: A social class theory of corporate acquisitions in the 1960s. Administrative Science Quarterly, 46, 87-120.

Pascale, R. (1985). The paradox of "Corporate Culture": Reconciling ourselves to socialization. California Management Review, 27(2), 26 - 41.

Petriglieri, J. L. (2011). Under threat: Responses to and the consequences of threats to individuals' identity. Academy of Management Review, 36, 641-662.

Pike, G. R., \& Kuh, G. D. (2005). First- and Second-Generation college students: A comparison of their engagement and intellectual development. The Journal of Higher Education, 76, 276-300. 
Organizational Culture and Impact on Business Opportunities and Advancement

Podolny, J. M. \& Baron, J. N. (1997). Resources and relationships: social networks and mobility in the workplace. American Sociological Review, 62, 673-93.

Ragins, B., \& Kram, K. (2007). The handbook of mentoring at work: Theory, research and practice. Thousand Oaks, CA: Sage.

Rakoczy, H., \& Schmidt, M. F. H. (2013). The early ontogeny of social norms. Child Development Perspectives, 7, 17-21.

Restubog, S. L. D., Zagenczyk, T. J., Bordia, P., Bordia, S., \& Chapman G. J. (2015). If you wrong us, shall we not revenge? Moderating roles of self-control and perceived aggressive work culture in predicting responses to psychological contract breach. Journal of Management, 41, 1132-1154.

Rivera, L. (2012). Hiring as cultural matching: The case of elite professional service firms. American Sociological Review, 77, 999 - 1022.

Roberts, L. M. (2005). Changing faces: Professional image construction in diverse organizational settings. Academy of Management Review, 30, 685-711.

Roberts, L. M., Dutton, J. E., Spreitzer, G. M., Heaphy, E. D., \& Quinn, R. E. (2005). Composing the reflected best-self portrait: Building pathways for becoming extraordinary in work organizations. Academy of Management Review, 30, 712-736.

Robinson, S. L., O’Reilly, J., \& Wang, W. (2013). Invisible at work an integrated model of workplace ostracism. Journal of Management, 39, 203-231.

Sangganjanavanich, V., Lenz, S., \& Cavazos, J. (2011). International students' employment search in the United States: a phenomenological study. Journal of Employment Counseling, 48, 17-26.

Schaubroeck, J. M., Peng, A. C., \& Hannah, S. T. (2013). Developing trust with peers and leaders: Impacts on organizational identification and performance during entry. Academy of Management Journal, 56, 1148-1168.

Schein, E. H. (1996). Culture: The missing concept in organization studies. Administrative Science Quarterly, 41, 229-240.

Seong, J. Y., Kristof-Brown, A. L., Park, W., Hong, D., \& Shin, Y. (2015). Person-Group Fit: Diversity Antecedents, Proximal Outcomes, and Performance at the Group Level. Journal of Management, 41, 1184-1213.

Sipe, S., Larson, L., McKay, B., \& Moss, J. (2016). Taking off the blinders: A comparative study of University students' changing perceptions of gender discrimination in the workplace from 2006 to 2013. Academy of Management Learning \& Education, 15, 232-249.

Srull, T. K., \& Wyer, R. S., Jr. (1989). Person memory and judgment. Psychological Review, 96, 58-83. 
Organizational Culture and Impact on Business Opportunities and Advancement

Stohl, C. (1986). The role of memorable messages in the process of organizational socialization. Communication Quarterly, 34, 231-249.

Sutarjo (2011). Ten ways of managing person-organization fit (P-O Fit) effectively: A literature study. International Journal of Business and Social Science, 2(21), 226-233.

Tate, K. A., Caperton, W., Kaiser, D., Pruitt, N. T., White, H., \& Hall, E. (2015). An Exploration of FirstGeneration College Students' Career Development Beliefs and Experiences. Journal of Career Development, 42, 294-310.

Tesser, A. (2000). On the confluence of self-esteem maintenance mechanisms. Personality and Social Psychology Review, 4, 290-299.

Tetlock, P. E. (1983). Accountability and the perseverance of first impressions. Social Psychology Quarterly, 46, 285-292.

Tyler, K. (2007). Cross-cultural connections. HR Magazine, 52(10), 77-82.

Wallace, G. (2015). Only 5 black CEOs at 500 biggest companies. CNN. Retrieved from http://money.cnn.com/2015/01/29/news/economy/mcdonalds-ceo-diversity/?iid=EL, accessed July $14,2016$.

Westphal, J. D., \& Stern, I. (2007). Flattery will get you everywhere (especially if you are a male Caucasian): How ingratiation, boardroom behavior, and demographic minority status affect additional board appointments at U.S. companies. Academy of Management Journal, 50, 267-288.

White, B. J. (2009). Addressing career success of African Americans in the workplace: An undergraduate business program intervention. The Career Development Quarterly, 58, 71-76.

Wolff, H., \& Moser, K. (2009). Effects of networking on career success: A longitudinal study. Journal of Applied Psychology, 94, 196-206.

Zhang, M., Xia, J., Fan, D., \& Zhu, J. (2016). Managing student diversity in business education: Incorporating campus diversity into the curriculum to foster inclusion and academic success of international students. Academy of Management Learning \& Education, 15, 366-380.

Zarya, V. (2016). The Percentage of Female CEOs in the Fortune 500 Drops to 4\%. Fortune. Retrieved from http://fortune.com/2016/06/06/women-ceos-fortune-500-2016/. Accessed July 14, 2016.

Zweigenhaft, R. L., \& Domhoff, G. W. (2006). Diversity in the power elite: How it happened, why it matters. Lanham, MD: Rowman \& Littlefield. 